\title{
COLORECTAL CANCER: factors related to late diagnosis in users of the public health system treated at an Universitary Hospital in Curitiba, Paraná State, Brazil
}

\author{
Rosa Helena Silva SOUZA ${ }^{1,2}$, Eliane Mara Cesário Pereira MALUF ${ }^{1,3}$, \\ Maria Cristina SARTOR ${ }^{4,5}$ and Denise Siqueira de CARVALHO ${ }^{6}$
}

Received 27/10/2015

\begin{abstract}
Background - The fourth most frequent tumor in the world, colorectal cancer is commonly diagnosed at an advanced stage. Objective - To analyze factors that interfere in the diagnosis of colorectal cancer in users of the Public Health System treated at an universitary hospital in Curitiba, Paraná State, Brazil. Methods - Cross-sectional, quantitative and descriptive study with 120 patients treated at the institution between 2012 and 2013. Data collection, carried out by means of medical record appointments and patients' interviews, addressed sociodemographic variables; clinical profile; timespan between symptoms, examination, diagnosis, treatment onset and difficulties encountered. Statistical analyses were performed by means of Stata 8.0. Results - Abdominal pain was the most frequent complaint and rectal bleeding presented the highest chance of advanced colorectal cancer diagnosis. From $52.5 \%$ of patients with late diagnosis of colorectal cancer, $81 \%$ reported difficulties in the health system. Conclusion - Results suggest that late diagnosis is due to symptom absence in the early stage of the disease, patients' lack of perception about the severity of the symptoms, need of better of health teams to search early diagnosis. Educational interventions are deemed necessary to the population and health teams, besides actions prioritizing the access to diagnostic testing for serious illnesses.
\end{abstract}

HEADINGS - Colorectal neoplasms. Diagnosis. Health services accessibility. Epidemiology.

\section{INTRODUCTION}

The last world assessment by the International Agency for Research on Cancer (IARC), found colorectal cancer $(\mathrm{CRC})$ as the third most frequent type among men and second among women ${ }^{(8)}$. In Brazil, according to estimates of Instituto Nacional do Câncer (INCA) - National Institute of Cancer, this tumor was responsible for about 32,000 new cases in $2014^{(6,10)}$, accounting for 15,070 new cases for males, and 17,530 new cases for females ${ }^{(11)}$.

The natural history of CRC provides ideal conditions for its prevention and early detection as it usually develops from benign lesions gradually for 10 or 15 years, comprising a long pre-clinic detectable period. This enables not only disease prevention, but also its diagnosis and treatment in early stages ${ }^{(0,20,25)}$ which may rise survival rate to $90 \%$ in 5 years $^{(5)}$. On the other hand, the chance of cure for metastatic cancer, diagnosed in stage IV, is almost non-existent, in spite of treatment advances ${ }^{(21)}$.

Early cancer detection is one of the most relevant phases in any oncology control programs. Diagnosis delay implies in a more aggressive therapeutic approach, lessens the opportunity to undergo conservative treatments, has a negative influence on life expectation and increases death rates ${ }^{(17)}$.

In Brazil, $55 \%$ to $70 \%$ of patients with colorectal cancer are diagnosed with the disease in advanced clinical stage (CS III and IV), which contributes to worsen prognosis ${ }^{(24)}$. Symptoms are common and non-specific in the early stages of the disease, requiring better assessment on the part of primary health care teams, referring patients to specialists faster, and performance of specific exams to diagnose malign tumors on due time for effective treatment $t^{(3,14)}$.

Declared conflict of interest of all authors: none

Disclosure of funding: no funding received

'Programa de Pós Graduação em Medicina Interna, Universidade Federal do Paraná, Curitiba, PR, Brasil; ${ }^{2}$ Serviço de Epidemiologia Hospitalar, Hospital de Clínicas, Universidade Federal do Paraná Curitiba, PR, Brasil. ${ }^{3}$ Departamento de Clínica Médica, Universidade Federal do Paraná, Curitiba, PR, Brasil: 4 Departamento de

Cirurgia do Hospital de Clínicas, Universidade Federal do Paraná, Curitiba, PR, Brasil; ${ }^{5}$ Serviço de Coloproctologia, Universidade Federal do Paraná, Curitiba, PR, Brasil;

${ }^{6}$ Departamento de Saúde Comunitária, Universidade Federal do Paraná, Curitiba, PR, Brasil.

Correspondence: Rosa Helena Silva Souza. Rua Fernandes de Barros, 101, ap. 22. Cristo Rei - CEP: 80050-310 - Curitiba, PR, Brasil. E-mail: rosahelena@ufpr.br 
By analyzing CRC cases at the studied hospital between 2003 and 2008, a significant inverse survival relationship in 5 years was observed according to the disease stages, taking up $100 \%$ for CS IV ${ }^{(23)}$.

Investigation performed by Cancer Hospital Register showed that $53 \%$ of colorectal cancer bearers admitted for treatment in 2009 were in the advanced stage of the disease. About 30\% died as late as 18 months after diagnosis. These facts brought about inquiries in relation to the conditions determining health/disease process: if treatment search occurred late or it was hindered by primary health care service, and/or forwarding to the reference network.

Knowing patients' disease process who had access to treatment enables to think over the kind of health care offered to users and community. Thus, this study objectifies to analyze the factors that may hinder colorectal cancer diagnosis in users of the Unified Health System (SUS) treated at a teaching hospital in Curitiba, Paraná State, Brazil.

\section{METHODS}

It is a cross-cut, quantitative, descriptive study of cases with colorectal cancer diagnosis identified at a public teaching hospital in the capital of Paraná State treated between January 1st, 2012 and December 31st, 2013, which complied with the inclusion criteria defined by: diagnostic confirmation of CRC by means of the anatomopathological exam and the possibility of providing the information required in the interview.

Research participants were selected from pathological anatomy reports diagnosing malignant colon cancer, rectosigmoid joint or rectum, according to $\mathrm{C} 18, \mathrm{C} 19$ and $\mathrm{C} 20$ codes, under the International Statistical Classification of Diseases $^{(18)}$ registered in the Hospital Information System of the institution.

Then, the search for each patient's hospital record was carried out to collect information on diagnosis, tumor location, histological type, CS, lymph node involvement, presence of metastasis and selected treatment. The collected data were transcribed for the research instrument.

Patients' contact was held at the moment of the consultation or subsequent hospitalization for case diagnosis. After presenting the study objectives and reading of the Free Consent Form and respective agreement, data collection was proceeded by means of a questionnaire applied during the interview. The questionnaire searched for sociodemographic information and clinical characteristics using open and closed questions related to symptoms, access to health care services and disease diagnosis. The research instrument was extensive in order to identify possible case biases regarding staging degree.

Investigated sociodemographic variables were: sex, age, schooling, occupation, place of origin and ethnicity. Variables regarding smoking and alcoholism habits were categorized yes/no. In order to analyze the clinical profile, dichotomous variables (present/absent) were used concerning the symptoms as follows: abdominal or anal pain, weight loss, weakness, gastric insufflation, presence of bleeding (in faeces or rectal), flatulence, diarrhea, constipation and anemia; also family history of cancer in general, and specific for CRC. Clinical staging was classified according to TNM System ${ }^{(12)}$ and location of the tumor was classified according to the Oncology International Statistical Classification of Diseases ${ }^{(12)}$. In order to evaluate the conditions of the disease diagnosis, variables regarding time intervals categorized by months were used ( $<1$ month; 1 to $\leq 3$ months; $>3$ to $\leq 6$ months; $>6$ to $\leq 12$ months; $>12$ months), calculated from the registers of the corresponding dates. The analyzed periods were: the onset of the symptoms until the search for medical care; the first consultation until diagnosis; the diagnosis until the onset of treatment. Variables concerning carrying out the proctological exam, request of specialized testing such as faecal occult blood, colonoscopy, rectosigmoidoscopy, tomography and abdominal echography, besides difficulties encountered during the case follow-up were categorized yes/no.

In order to minimize possible memory biases related to symptom onset and search for medical care, the questions were associated with meaningful dates such as holidays, birthdays or seasons of the year.

Database was organized in the Excel program and statistical analyses were carried out with Stata 8.0 software. For the quantitative variables, descriptive analyses were performed using average, median, minimum and maximum values and standard deviation. Categorical variables were presented in absolute frequencies and percentages ${ }^{(22)}$.

As for the bivariate analysis, clinical staging (CS) was considered the dependent variable, and advanced disease stage as the result of interest. Early stage cases were grouped in "A" category $(0, I$ and II), while the late stage cases were grouped in "B" category (III and IV CS). Variables featuring $P<0.20$ in the bivariate analysis were selected to comprise the model for logistic regression analysis.

The project was approved by the Ethics Research Board of Hospital de Clínicas in November, 2011 (CAEE 0273.0.208.000-11).

\section{RESULTS}

From 138 diagnosed CRC cases in the period, 120 participated in the study, accounting for $87 \%$. Among the 18 excluded cases, $16(11.6 \%)$ died before the interview, 1 for undergoing treatment in another institution, and 1 for cognitive impairment to answer the questions.

The disease was prevalent among women (57.5\%). Men's average age was higher than the observed among the women, 66 and 56 years old respectively. Most of them were white $(84.2 \%)$ and from Curitiba (62.5\%). Schooling in general was low (Table 1);37.5\% were smokers, and $20.8 \%$ had alcoholic beverages.

The presence of cancer in the family history was high (71.6\%), and $27.4 \%$ from those featured CRC (Table 2).

The disease was located in the colon in $56.7 \%$ of the cases, followed by rectum (36.2\%) and rectosigmoid junction $(7.1 \%)$. Synchronous cancers were recorded, that is, more than one tumor was simultaneously found during the diagnosis or surgery ${ }^{(1)}$ in $5.8 \%$ (Table 2 ). 
TABLE 1. Sociodemographic characteristics of patients with CRC treated in the institution, 2012 and 2013

\begin{tabular}{|c|c|c|c|}
\hline Characteristics & $\mathrm{n}$ & $\%$ & $P$ \\
\hline \multicolumn{4}{|l|}{ Sex } \\
\hline Female & 69 & 57.5 & 0.02 \\
\hline Male & 51 & 42.5 & \\
\hline Age range (in years)* & & & 0.000 \\
\hline$<30$ & 1 & 0.8 & \\
\hline 30 to 49 & 26 & 21.7 & \\
\hline 50 to 69 & 61 & 50.8 & \\
\hline 70 or older & 32 & 26.7 & \\
\hline Color & & & 0.000 \\
\hline White & 101 & 84.2 & \\
\hline Mulatto & 15 & 12.5 & \\
\hline Yellow & 1 & 0.8 & \\
\hline Black & 3 & 2.5 & \\
\hline Schooling* & & & 0.000 \\
\hline Illiterate & 9 & 7.7 & \\
\hline Incomplete middle school & 57 & 47.5 & \\
\hline Incomplete high school & 28 & 23.3 & \\
\hline High school & 20 & 16.7 & \\
\hline Higher education & 6 & 5.0 & \\
\hline Origin $* * *$ & & & 0.0001 \\
\hline Curitiba & 75 & 62.5 & \\
\hline Metropolitan area & 29 & 24.2 & \\
\hline Interior of Paraná State & 15 & 12.5 & \\
\hline Another State & 1 & 0.8 & \\
\hline $\begin{array}{l}\text { Occupation, according to the } \\
\text { Brazilian Classification of } \\
\text { Occupations }\end{array}$ & & & --- \\
\hline $\begin{array}{l}\text { Service and commerce workers in } \\
\text { stores and markets }\end{array}$ & 34 & 28.3 & \\
\hline $\begin{array}{l}\text { Workers of goods manufacturing } \\
\text { and industrial services }\end{array}$ & 26 & 21.7 & \\
\hline $\begin{array}{l}\text { Chairmen of public institutions } \\
\text { and companies, managers }\end{array}$ & 8 & 6.7 & \\
\hline Science and Arts Professionals & 7 & 5.8 & \\
\hline $\begin{array}{l}\text { Farming, forestry, hunting and } \\
\text { fishing workers }\end{array}$ & 7 & 5.8 & \\
\hline $\begin{array}{l}\text { Housekeeper or without any } \\
\text { occupations }\end{array}$ & 21 & 17.5 & \\
\hline Others & 17 & 14.1 & \\
\hline
\end{tabular}

* Chi-square measure of tendency. ** White category compared to others. *** Curitiba origin compared to other regions.
TABLE 2. Clinical characteristics of patients with CRC treated in the institution, 2012 and 2013

\begin{tabular}{lccc}
\hline Characteristics & $\mathbf{n}$ & $\%$ & $\boldsymbol{P}$ \\
\hline Family history of cancer & & & \\
$\quad$ Yes & 86 & 71.6 & 0.000 \\
Clinical staging* & & & 0.000 \\
0 & 7 & 5.8 & \\
I & 12 & 10.0 & \\
II & 38 & 31.7 & \\
III & 40 & 33.3 & \\
IV & 23 & 19.2 & \\
Symptoms* & & & --- \\
Abdominal pain & 83 & 69.2 & \\
Rectal bleeding & 73 & 60.8 & \\
Weight loss & 54 & 45.0 & \\
Constipation & 51 & 42.5 & \\
Diarrhea & 47 & 39.2 & \\
Weakness & 45 & 37.5 & \\
Flatulence & 40 & 33.3 & \\
Anemia & 30 & 25.0 & \\
Others & 14 & 11.7 & \\
Asymptomatic & 4 & 3.3 & \\
Tumor location*** & & & --- \\
C18 Colon & 72 & 56.7 & \\
C19 Rectosigmoid junction & 9 & 7.1 & \\
C20 Rectum & 46 & 36.2 & \\
\hline
\end{tabular}

* Chi-square measure of tendency. ** One or more symptoms referred by patients. *** Seven cases with two synchronous tumors.

It was observed that $52.5 \%$ of the patients had the disease diagnosed in an advanced stage. Most of them searched for medical care due to more than one symptom. Abdominal pain, isolated or associated, was the most frequent complaint in $69.2 \%$ of the patients (Table 2 ).

Timespan between the first symptoms and search for medical care, diagnosis and treatment onset was analyzed in months (Table 3 ).

After the beginning of the symptoms, average time until the search for treatment was 4 months and median time was 1 month, with $45 \%$ of the patients searching for medical care within 1 month, and $18.3 \%$ waited for over 6 months (Table 3 ).

Average timespan between the first medical consultation and cancer diagnosis was 7.45 months, with median time of 3.9 months. Among the 19 patients who were diagnosed within one month after the first medical consultation, $11(57.9 \%)$ featured special health condition: $8(42.5 \%)$ presented obstructive acute abdomen or perforated abdomen - condition requiring emergency care; $2(10.5 \%)$ had been admitted to hospital investigating other syndromes; and 1 was being investigated for Lynch syndrome, due to have first degree young family member with CRC.

Most patients $(84.2 \%)$ began treatment within 2 months after diagnosis (Table 3 ). 
TABLE 3. Timespan between the first symptoms, search for medical care, diagnosis and treatment onset

\begin{tabular}{|c|c|c|c|c|c|c|c|c|}
\hline \multirow[t]{2}{*}{$\begin{array}{l}\text { Period } \\
\text { (in months) }\end{array}$} & \multicolumn{2}{|c|}{$\begin{array}{l}\text { Timespan between the first } \\
\text { symptoms and search for } \\
\text { medical care }\end{array}$} & \multicolumn{2}{|c|}{$\begin{array}{l}\text { Timespan between the first } \\
\text { Symptoms and Diagnosis }\end{array}$} & \multicolumn{2}{|c|}{$\begin{array}{c}\text { Timespan between the } \\
\text { first consultation and } \\
\text { diagnosis }\end{array}$} & \multicolumn{2}{|c|}{$\begin{array}{l}\text { Timespan between } \\
\text { Diagnosis and treatment }\end{array}$} \\
\hline & $\mathrm{n}$ & $\%$ & $\mathrm{n}$ & $\%$ & $\mathrm{n}$ & $\%$ & $\mathrm{n}$ & $\%$ \\
\hline Within 1 & 54 & 45.0 & 12 & 10.0 & 19 & 15.8 & 68 & 56.7 \\
\hline$>1$ to $\leq 3$ & 27 & 22.5 & 15 & 12.5 & 29 & 24.2 & 41 & 34.2 \\
\hline$>3$ to $\leq 6$ & 17 & 14.2 & 23 & 19.2 & 32 & 26.7 & 6 & 5.0 \\
\hline$>6$ & 22 & 18.3 & 70 & 58.3 & 40 & 33.3 & 5 & 4.2 \\
\hline Total & 120 & 100.0 & 120 & 100.0 & 120 & 100.0 & 120 & 100.0 \\
\hline
\end{tabular}

The most requested exams in the first consultation were colonoscopy (23.3\%), search for faecal occult blood (8.3\%), rectosigmoidoscopy (2.4\%), abdominal echography $(4.0 \%)$, abdominal computerized tomography $(4.0 \%)$. However, not all of them were performed (like the greatest part of the colonoscopies) due to vacancy unavailability in the Unified
Health System network. The proctological exam was held in $28.3 \%$ of the patients.

In the bivariate analysis, for anal bleeding (Table 4), timespan between the first consultation and diagnosis, as well as hindrances in the Health Care Services evidenced statistically meaningful association with disease staging.

TABLE 4. Bivariate analysis between potential factors associated with advanced clinical staging

\begin{tabular}{|c|c|c|c|c|c|c|}
\hline \multirow[b]{2}{*}{ Variables } & & \multicolumn{2}{|c|}{ Clinical stage } & \multirow[b]{2}{*}{ OR } & \multirow[b]{2}{*}{$(95 \% \mathrm{CI})$} & \multirow[b]{2}{*}{$P($ chi-square $)$} \\
\hline & & A $(0, \mathrm{I}, \mathrm{II})$ & $\begin{array}{l}\text { B (III,IV) } \\
\mathrm{n}=63(\%)\end{array}$ & & & \\
\hline \multirow[t]{2}{*}{ Sex } & Male & $27(47.4)$ & $24(38.1)$ & & & \\
\hline & Female & $30(52.6)$ & $39(61.9)$ & 1.46 & $(0.70-3.05)$ & 0.31 \\
\hline \multirow[t]{4}{*}{ Age range } & & & & 0.64 & $(0.38-1.06)$ & 0.09 \\
\hline & $<50$ & $10(17.5)$ & $17(27.0)$ & & & \\
\hline & 50 to 69 & $28(49.1)$ & $33(52.4)$ & & & \\
\hline & 70 and older & $19(33.3)$ & $13(20.6)$ & & & \\
\hline \multirow[t]{4}{*}{ Schooling } & & & & 0.82 & $(0.53-1.27)$ & 0.37 \\
\hline & None/ Incomp Middle School & $30(52.6)$ & $36(57.1)$ & & & \\
\hline & Incomp. Middle School & $12(21.1)$ & $16(25.4)$ & & & \\
\hline & High School/ Higher Education & $15(26.3)$ & $11(17.5)$ & & & \\
\hline \multirow[t]{2}{*}{ Color } & White & $47(82.5)$ & $54(85.7)$ & & & \\
\hline & Non-white & $10(17.5)$ & $9(14.3)$ & 0.78 & $(0.29-2.10)$ & 0.63 \\
\hline \multirow[t]{2}{*}{ Origin } & Curitiba & $39(68,4)$ & $36(57,1)$ & & & \\
\hline & Metropolitan Area and int. & $18(31.6)$ & $27(42.9)$ & 1.63 & $(0.76-3.46)$ & 0.20 \\
\hline \multicolumn{7}{|l|}{ Symptoms } \\
\hline Abdominal pain & Yes & $39(68.4)$ & $44(69.8)$ & 1.07 & $(0.49-2.33)$ & 0.87 \\
\hline Rectal bleeding & Yes & $27(47.4)$ & $46(73.0)$ & 3.01 & $(1.36-6.64)$ & 0.004 \\
\hline Diarrhea & Yes & $19(33.3)$ & $28(44.4)$ & 1.6 & $(0.76-3.39)$ & 0.22 \\
\hline Constipation & Yes & $24(42.1)$ & $27(42.9)$ & 1.03 & $(0.50-2.14)$ & 0.93 \\
\hline \multicolumn{7}{|c|}{ Family history of cancer } \\
\hline & Yes & $41(71.9)$ & $45(71.4)$ & 0.98 & $(0.44-2.17)$ & 0.95 \\
\hline Smoking & Yes & $26(45.6)$ & $19(30.2)$ & 0.51 & $(0.24-1.10)$ & 0.08 \\
\hline Alcoholism & Yes & $13(22.8)$ & $12(19.0)$ & 0.80 & $(0.33-1.93)$ & 0.61 \\
\hline \multicolumn{7}{|c|}{ Location of the tumor * } \\
\hline & Colon & $35(63.9)$ & $30(49.2)$ & 0.55 & $(0.26-1.16)$ & $0.12 * *$ \\
\hline & Rectosigmoid junction & $3(5.5)$ & $6(9.8)$ & 1.89 & $(0.45-7.96)$ & $0.38 * *$ \\
\hline & Rectum & $17(30.9)$ & $25(41.0)$ & 1.55 & $(0.72-3.34)$ & $0.26 * *$ \\
\hline
\end{tabular}

* Four cases with two synchronous tumors excluded from the analysis due to rectal and colon location. ** Comparison of tumor location to other locations. 
Presence of anal bleeding featured positive association with later disease stage, OR of 3.01 ( $95 \%$ CI 1.36 - 6.64). Similarly, OR of $1.40(95 \%$ CI $1.01-1.96)$ for timespan between the first consultation and $\mathrm{CRC}$ diagnosis (Table 5).

Most patients $(83.2 \%)$ with CRC in late clinical stage reported hindrances in the health service. By performing probable association of these problems with late CS was found OR 4.61, (95\% CI 1.74 - 12.26). The main reported problems were: delay or lack of access to specialized health care or tertiary health care $(26.5 \%)$; need to pay for medical consultation or diagnostic testing for delay or unavailability in the Unified Health System (24.5\%); medical disregard at the Primary Health Care Unit $(12.9 \%)$; delay for the first consultation $(3.2 \%)$; initial misleading/doubtful diagnosis $(3.9 \%)$. Some reported more than one reason for the hindrances, and $12.2 \%$ disregarded the symptoms.
It was observed that $34.2 \%$ of the diagnostic cancer tests were not subsidized by the Unified Health System, in spite of the patients having been under treatment at a public hospital. From $82.5 \%$ of the patients treated in the Unified Health System, 24.2\% paid for the diagnostic test.

In order to investigate if the studied variables were independent risk factors, they were adjusted through logistic regression (multivariate analysis). Variables with $P<0.20$ were selected, among them, "difficulties in the health care services" and "anal bleeding" continued being associated factors to late CRC diagnosis. The shortest timespan between the first symptoms and the search for medical care was associated with higher disease severity, with OR of $0.64(95 \%$ CI $0.45-0.92)$ (Table 6).

TABLE 5. Bivariate analysis between variable of health care services access and advanced clinical staging

\begin{tabular}{|c|c|c|c|c|c|}
\hline \multirow[b]{2}{*}{ Variables } & \multicolumn{2}{|c|}{ Clinical staging } & \multirow[b]{2}{*}{ OR } & \multirow[b]{2}{*}{$(95 \% \mathrm{CI})$} & \multirow[b]{2}{*}{$P$} \\
\hline & $\begin{array}{c}\mathrm{A}(0, \mathrm{I}, \mathrm{II}) \\
\mathrm{n}=57(\%) \\
\mathrm{n}(\%)\end{array}$ & $\begin{array}{c}\mathrm{B}(\mathrm{III}, \mathrm{IV}) \\
\mathrm{n}=63(\%) \\
\mathrm{n}(\%)\end{array}$ & & & \\
\hline Time between 1st symptom and consultation* & & & 0.78 & $(0.57-1.06)$ & 0.11 \\
\hline$<1$ month & $25(43.9)$ & $29(46.0)$ & & & \\
\hline $1 \leq 3$ months & $9(15.8)$ & $17(27.0)$ & & & \\
\hline$>3 \leq 6$ months & $7(12.3)$ & $11(17.5)$ & & & \\
\hline$>6$ months & $16(28.0)$ & $6(9.5)$ & & & \\
\hline Time between 1 st symptom and diagnosis* & & & 1.34 & $(0.95-1.91)$ & 0.10 \\
\hline$<1$ month & $8(14.0)$ & $4(6.4)$ & & & \\
\hline $1 \leq 3$ months & $8(14.0)$ & $6(9.5)$ & & & \\
\hline$>3 \leq 6$ months & $11(19.3)$ & $13(20.6)$ & & & \\
\hline$>6$ months & $30(52.7)$ & $40(63.5)$ & & & \\
\hline Time between consultation and diagnosis* & & & 1.40 & $(1.01-1.96)$ & 0.05 \\
\hline$<1$ month & $11(19.3)$ & $7(11.1)$ & & & \\
\hline $1 \leq 3$ months & $18(31.6)$ & $12(19.0)$ & & & \\
\hline$>3 \leq 6$ months & $12(21.1)$ & $20(31.7)$ & & & \\
\hline$>6$ months & $16(28.1)$ & $24(38.1)$ & & & \\
\hline Time between diagnosis and treatment* & & & 0.86 & $(0.54-1.37)$ & 0.52 \\
\hline$<1$ month & $31(54.4)$ & $37(58.7)$ & & & \\
\hline $1 \leq 3$ months & $20(35.1)$ & $21(33.3)$ & & & \\
\hline$>3 \leq 6$ months & $3(5.3)$ & $3(4.8)$ & & & \\
\hline$>6$ months & $3(5.3)$ & $2(3.2)$ & & & \\
\hline \multicolumn{6}{|l|}{ Difficulties } \\
\hline No difficulties & $19(33.3)$ & $7(11.1)$ & 1.00 & - & - \\
\hline Related to the patient & $8(14.0)$ & $5(7.9)$ & 1.69 & $(0.41-6.98)$ & 0.46 \\
\hline With the health care service & $30(52.6)$ & $51(81.0)$ & 4.61 & $(1.74-12.26)$ & $<0.01$ \\
\hline \multicolumn{6}{|l|}{ Consultation } \\
\hline Private & $11(19.3)$ & $10(15.9)$ & 1.00 & - & - \\
\hline SUS & $46(80.7)$ & $53(84.1)$ & 1.27 & $(0.49-3.26)$ & 0.62 \\
\hline \multicolumn{6}{|l|}{ Diagnostic testing } \\
\hline Private & $16(28.1)$ & $25(39.7)$ & 1.00 & - & - \\
\hline SUS & $41(71.9)$ & $38(60.3)$ & 0.59 & $(0.28-1.28)$ & 0.18 \\
\hline
\end{tabular}

\footnotetext{
* Chi-square measure of tendency.
} 
TABLE 6. Multivariate analysis: factors associated with advanced CS

\begin{tabular}{|c|c|c|c|c|}
\hline Variables & Unadjusted OR & $(95 \% \mathrm{CI})$ & Adjusted OR & $(95 \% \mathrm{CI})$ \\
\hline Time between 1 st symptom and consultation & 0.78 & $(0.57-1.06)$ & 0.64 & $(0.45-0.92)$ \\
\hline Difficulties related to the health care service & 4.61 & $(1.74-12.26)$ & 2.25 & $(1.36-3.72)$ \\
\hline Rectal bleeding & 3.01 & $(1.36-6.64)$ & 3.45 & $(1.49-8.02)$ \\
\hline
\end{tabular}

\section{DISCUSSION}

Several international experiences show successful results in planned CRC prevention and control, population awareness, fecal occult blood testing for people between 50 and 74 years of age, besides the allocation of resources for fast diagnosis and treatment, with participation of primary health care and organization of all health care levels ${ }^{(2)}$.

Faecal occult blood testing is recommended as the method of screening for secondary prevention and early CRC diagnosis for people with 50 years of age or older every year or 2 years, followed by colonoscopy for positive cases ${ }^{(2)}$. However, among the patients in this study, the faecal occult blood testing was requested for only $10(8.3 \%)$ patients, of those 3 were below 50 years old, and 3 were over 75 years of age, suggesting low awareness of health professionals on referral and importance of CRC screening, mainly among the teams in the Primary Health Care ${ }^{(22)}$.

Although colorectal cancer screening may reduce mortality rate by detecting and removing early precursor lesions ${ }^{(26)}$, rates of this practice have been low in Brazil. This fact can be attributed to patients' resistance to search for medical care; among the doctors, they don't deepen diagnostic investigation; or the health care system itself which does not provide proper resources for that ${ }^{(13)}$.

In this study, it was observed that anal bleeding was the risk factor for late CRC diagnosis. It is widely known the fact that anal bleeding is associated to hemorrhoids or any benign anal, rectal problems, when common symptoms to most anal, rectal conditions do not call attention until they change into more serious illnesses ${ }^{(7,16,19)}$.

Twenty-five per cent attributed their health problem to hemorrhoids, $4.2 \%$ did not suspect it could be cancer, and $10 \%$ disregarded the symptoms, factors which may have contributed to the diagnosis delay. It deems necessary to point out the importance of the symptoms among the patients, besides the development of actions in order to forward diagnosis and adequate analysis performed by health professionals, as time taken for the diagnosis interferes negatively in the evolution and prognosis.

Errors in the initial diagnosis, inadequate evaluation and imprecise investigations also increase diagnosis time. Symptoms of the lower gastrointestinal tract are frequent in patients who search for primary health care, and proper referral is a major challenge ${ }^{(16)}$. Several technologies are used to confirm CRC, however undergoing the proctological exam may evidence rectal lesions and speed up the diagnosis process. This exam was performed in only $30 \%$ of the studied patients, corroborating research studies which point out that rectal examination is not held in 25 to $75 \%$ of patients with symptoms ${ }^{(15)}$.

Moreover, $70.3 \%$ of the patients held the public health care service responsible for hindrances leading to diagnosis delay, mentioning care disregard, error in the initial diagnosis and, above all, unavailable appointments for exams or specialist consultations which kept them in a waiting line.

Lack of access of the population, and difficulty in getting medical and technological resources may lead to late cancer diagnosis, when the disease becomes incurable and treatment is palliative $\mathrm{e}^{(4)}$. For $52.5 \%$ of the patients in this research, disease diagnosis was late.

Most patients $(84.2 \%)$ began treatment within 2 months after the diagnosis, probably due to the institution characteristics: teaching hospital with academic interest in investigation and fast treatment.

Multivariate analysis evidenced that some patients who took longer to search for medical care had diagnosis in an earlier stage. The explanation may lie in a reverse condition, that is, faster medical care is due to more severe symptoms. Therefore, it deems necessary to carry out public campaigns of screening and population awareness to the problem.

Among the $62.5 \%$ of patients from the State capital, where more resources for the health area have been allocated, average time taken between the first consultation, disregarding the symptom onset, and the diagnosis was 6.8 months, median time of 3.9 months. This fact evidences that it is necessary more problem-solving, involvement and autonomy on the part of primary health care professionals for referrals and exam appointments so that problems be solved in the shortest possible time.

\section{CONCLUSION}

The study showed that CRC diagnosis has been featured late in public health care services in the region either for delay in referrals or difficulty in the access to specialized services and diagnostic exams, besides the disregard of symptoms on the part of the health team or the patients. 
The results suggest that it is necessary to reduce the time until CRC diagnosis: to warn the population for the importance of the unspecified symptoms usually taken as meaningless, by means of awareness campaigns and disease investigation; to promote behavioral change in all health team so that they perform deeper clinical exams and referrals on due time; and to discuss with health authorities on the need of increasing the offer of diagnostic testing and specialized consultations for screening and diagnosis.

The World Health Organization recommends that strategies for early diagnosis be implemented, touting the warning signs widely to the population and health professionals, immediate access to diagnostic procedures in suspected cases by expanding the offer of these services, as well as access to adequate and suitable treatment ${ }^{(5)}$.

\section{Authors' contributions}

Souza RHS: data collection, research implementation, article elaboration. Maluf EMCP: advisory and text revision. Sartor MC: advisory, writing and text revision. Carvalho DS: statistical analysis, table elaboration, revision.

Souza RHS, Maluf EMCP, Sartor MC, Carvalho DS. Câncer colorretal: fatores relacionados ao diagnóstico tardio dos usuários do SUS atendidos em Hospital Universitário de Curitiba. Arq Gastroenterol. 2016,53(2): 68-75.

RESUMO - Contexto - Quarto tumor mais frequente no mundo, o câncer colorretal comumente é diagnosticado em estádio avançado. Objetivo - Analisar fatores que interferem no diagnóstico do câncer colorretal de usuários do Sistema Único de Saúde, atendidos em hospital universitário de Curitiba.

Métodos - Estudo transversal, quantitativo e descritivo com 120 pacientes atendidos na instituição em 2012 e 2013 . A coleta de dados, realizada por meio de consulta ao prontuário e entrevista aos pacientes, abordou variáveis sociodemográficas; perfil clínico; tempo decorrido entre sintomas, atendimento, diagnóstico e início do tratamento e dificuldades encontradas. As análises estatísticas foram feita com pelo Stata 8.0. Resultados - Dor abdominal foi a queixa mais frequente e sangramento retal representou maior chance de diagnóstico avançado de câncer colorretal. Dos $52,5 \%$ dos pacientes que diagnosticaram a doença tardiamente, $81 \%$ relataram dificuldades com o serviço de saúde. Conclusãa - Os resultados sugerem que o diagnóstico tardio é devido à ausência de sintomas na fase inicial da doença, falta de percepção dos pacientes sobre a gravidade dos sintomas, necessidade de maior preparo das equipes de saúde para o diagnóstico precoce. São necessárias intervenções educativas junto à população e equipes de saúde, além de ações que priorizem o acesso a exames diagnósticos de doenças graves.

DESCRITORES - Neoplasias colorretais. Diagnóstico. Acesso aos serviços de saúde. Epidemiologia. 


\section{REFERENCES}

1. Andrade SMS; Pereira FL. Câncer Colorretal Sincrônico - Relato de Caso e Revisão de Literatura. Rev Bras Colo-Proct. 2007;27:69-79.

2. Assis RVBF. Rastreamento e Vigilância do Câncer Colorretal: Guidelines Mundiais. GED. 2011:30:62-74. [Internet]. [cited October, 2015]. Available from: http:// files.bvs.br/upload/S/0101-7772/2011/v30n2/a2916.pdf

3. Astin M, Griffin T, Neal RD, Rose P, Hamilton W. The diagnostic value of symptoms for colorectal cancer in primary care: a systematic review. Br J Gen Pract. 2011;61:e231-43.

4. Bertges ER, Moraes-Filho JPP. Câncer Colorretal: rastreamento e vigilância. GED. 2006;25:110-8.

5. Brasil. Ministério da Saúde. Secretaria de Atenção à Saúde. Departamento de Atenção Básica. Rastreamento. Brasília: Ministério da Saúde; 2010.

6. Diniz FF, Perondi F, Gonçalves JA. Epidemiologia e fatores de risco. In: Campos FGM, Regadas FSP, Pinho MSL. Tratado de coloproctologia. São Paulo: Atheneu; 2012.

7. Esteva M, Leiva A, Ramos M, Pita-Fernández S, González-Luján L, Casamitjana $\mathrm{M}$, et al. Factors related with symptom duration until diagnosis and treatment of symptomatic colorectal cancer. BMC Cancer. 2013;13:87.

8. GLOBOCAN 2012: Estimated Cancer Incidence, Mortality and Prevalence Worldwide in 2012. [Internet]. [cited October, 2015]. Available from: http://globocan. iarc.fr/Pages/fact_sheets_population.aspx.

9. Habr-Gama A, Campos FGCM, Perez RO, São Julião GP, Proscurshim I. Prevenção e rastreamento do câncer colorretal. In: Campos FGM, Regadas FSP, Pinho MSL. Tratado de coloproctologia. São Paulo: Atheneu; 2012.

10. Instituto Nacional de Câncer. Estimativa 2012: incidência de câncer no Brasil. Rio de Janeiro: INCA; 2011. 118p. [Internet]. [cited October, 2015]. Available from: http://www1.inca.gov.br/estimativa/2012/.

11. Instituto Nacional de Câncer. Estimativa 2014: incidência de câncer no Brasil Rio de Janeiro: INCA; 2014. [Internet]. [cited October, 2015]. Available from: http://www.inca.gov.br/estimativa/2014/

12. Instituto Nacional de Câncer. TNM: classificação de tumores malignos. 7.ed. Rio de Janeiro: INCA; 2010

13. Instituto Nacional do Câncer. A situação do câncer no Brasil. Coordenação de Prevenção e Vigilância de Câncer. Rio de Janeiro: INCA; 2006.

14. Jellema P, van der Windt DA, Bruinvels DJ, Mallen CD, van Weyenberg SJ, Mulder $\mathrm{CJ}$, de Vet HC. Value of symptoms and additional diagnostic tests for colorecta cancer in primary care: systematic review and meta-analysis. BMJ. 2010;340:c1269.
15. Langenbach MR, Schmidt J, Neumann J, Zirngibl H. Delay in treatment of Colorectal Cancer: Multifactorial problem. World J Surg. 2003,27:304-8.

16. Mitchell E, Mcdonald S, Campbell NC, Weller D, Macleod U. Influences on pre-hospital delay in the diagnosis of colorectal cancer: a systematic review. $\mathrm{Br}$ J Cancer. 2008;98:60-70.

17. Naffah Filho M, Cecílio MA. Subsídios para um novo modelo de atenção ao câncer no Estado de São Paulo. Rev. Adm. Saúde. 2005.;7:95-111.

18. Organização Mundial da Saúde. CID-10 Classificação Estatística Internacional de Doenças e Problemas Relacionados à Saúde. 10.ed. São Paulo: Universidade de São Paulo; 2007. v.3.

19. Pedersen AF, Hansen RP, Vedsted P. Patient Delay in Colorectal Cancer Patients: Associations with Rectal Bleeding and Thoughts about Cancer. PLoS One. 2013;8:e69700.

20. Sartor MC. Comparação entre a apoptose celular, a expressão de antígeno carcinoembrionário e do P53 em pólipos colônicos benignos e câncer. [Dissertation] São Paulo: Faculdade de Medicina da Universidade de São Paulo; 2000

21. Schmiegel W, Pox C, Adler G, Fleig W, Fölsch UR, et al. [S3-Guidelines Conference "Colorectal Carcinoma" 2004]. Z Gastroenterol. 2004;42:1129-77.

22. Secretaria Municipal da Saúde (São Paulo). Coordenação de Epidemiologia e Informação - CEInfo. Boletim CEInfo Análise. 2012nov.;6.

23. Souza RHS, Stockli JV, Luhm KR, Sartor MC, Maluf EMC, Carvalho DS, Klimczuk MF. Perfil epidemiológico e sobrevida em cinco anos dos casos de câncer colorretal atendidos no HC/UFPR no período de 2003 a 2008. IX Congresso Brasileiro de Epidemiologia. Rio de Janeiro: ABRASCO; 2014. [Internet] [cited October, 2015]. Available from: http://www.epiabrasco.com.br/ ANAIS-EPIVIX-2014.pdf

24. Valadão M, Leal RA, Barbosa LC, Carneiro M, Muharre RJ. Perfil dos pacientes portadores de câncer colorretal operados em um hospital geral: necessitamos de um programa de rastreamento acessível e efetivo. Rev Bras Colo-Proctol. 2010;30:160-6. [Internet]. [cited October, 2015] Available from: http://www.scielo.br/scielo.php?script=sci_arttext\&pid=S0101-98802010000200006\&lng=en.

25. Winawer S, Fletcher R, Rex D, Bond J, Burt R, Ferrucci J, et al. Colorectal cancer screening and surveillance: clinical guidelines and rationale - update based on new evidence. Gastroenterology. 2003;130:1872-85.

26. Zentralinstitut der Kassenärztlichen Versorgung: Wissenschaftliches Begleitprogramm zur Früherkennungskoloskopie. 11/2008. [Internet]. [cited October, 2015]. Available from: http://daris.kbv.de/daris.asp 